\title{
Torture without physical pain: Inside cell 24 of the special wing for political prisoners-Evin prison (Iran)
}

\author{
Hasti Irani
}

I come from Iran, an immense country of more than 77 million inhabitants, the cradle of Persian civilization, and one of the richest and most ancient cultural traditions of humankind, with deep values of respect and tolerance. 38 years ago there was an Islamic revolution that turned Iran into a country that has Islam as an official religion and in which laws must conform to Sharia or Islamic law. I belong to the Christian minority, officially recognised in the Iranian constitution, but only for those born in an ethnically Christian family. People who, like me, were born into an Islamic family and converted to Christianity, are considered apostates and guilty of a serious crime under Sharia. In the last year alone about 200 people who have been accused of apostasy have been imprisoned and many have been tortured. That was the reason I was detained. We Christians are no threat to the national security of Iran. We are not going against the State. But we are treated as such. We, although citizens of Iran, are under Criminal Law, the Enemy.

Each city in Iran has at least one prison. The largest, Evin prison, in Tehran, is a huge

\footnotetext{
${ }^{i}$ Hasti Irani is a pseudonym due to security and family reasons. She is presently in exile.

ii Section 209 of the Evin prison is an unofficial and secret detention centre in Tehran, Iran, that operates under the administration of VAJA, the Islamic Republic of Iran's Ministry of Intelligence. It contains 90 solitary confinement cells.

Correspondence to: publications@irct.org
}

set of buildings that houses 12,000 prisoners. Section $2 \mathrm{~A}$ and $209^{\text {ii }}$ houses the Special Prisoners, political detainees, usually amounting to more than two hundred persons. After interrogation and torture many of them are transferred to Section 350, where political prisoners are under conditions of extreme psychological torture. And this is only Tehran. Every city has its prisons, although there is little news about them. Life in Iran feels like being in a large prison that houses many smaller detention centres within it.

In Iran, students, journalists, lawyers, film directors ... are imprisoned for opinion crimes. There are no legal guarantees. Courts are religious courts.

The wings for political prisoners in Evin Prison are not like the others. They were once designed with international assessment to create an environment best suited to psychological torture. I would like to share my experience as a person who was arrested and tortured in the wing for political detainees at Evin Prison. Rebuilding this story has taken years. Rebuilding the story began five years ago when an Istanbul Protocol assessment was filled in. It hardly managed to record even a part of my experience. It was simply not my time to talk. The first damage of psychological torture is that it is not possible to speak of it. It's too deep and too painful. Difficult to explain and difficult to understand. Being able to write this text today is part of my path and a 
personal process with my therapist that allows me to finally look at my torturers' faces and defy them.

I was arrested at home and taken by three guards plus a driver, to Evin prison in the north of Tehran. I was dizzy with question: Why? Where? What for?! In the heavy traffic, I thought, "No one realises that in the car beside them they are taking someone to the destroying chambers to tumble her life for ever, and alter her outlook on life."

Dazed and baffled I arrived at the prison where one of my captors yelled at me to keep my head down and shoved a filthy blindfold to my chest to put on. As if coming out of a blackout I realised this is not a dream and that I was about to see shocking things. Walking blindfolded for the first time, the distance to the cells was extremely difficult. I took my steps in total blackness expecting to hit something or fall into a gully! With every step in this vacuum there was this feeling of an imminent plunge down a ravine. I just walked in darkness. Behind the blindfold, in this unknown space, I had a strange feeling for which I had no portrayal.

'Turn, left!' 'now turn right!'... and then I was handed over to another guard, behind whose sound of steps I now walked. He stopped somewhere and rang a bell for a new guard. He handed me over and said, 'It's yours!'

Again, I followed the sound of the footsteps. Somewhere she stopped and ordered me to go in. But where, I couldn't see. She asked me to take my blindfold off now because I had to undress. I found myself in a strange, tiny room - more like a cupboard. I didn't want to undress before her gaping eyes. I argued to no avail. She said, 'Do what I tell you!' Another one arrived but just stood by the door looking, as there was no room for her inside. There was no escape... How loathsome when someone probes your body up and down, as if you are for sale.

She wants you to sit on your feet and open your legs as far as possible. Repeat this several times ... You have no power. Only obey.

When this was finished, I found myself in a very small, filthy and cold cell that had white walls.

I had been thrown into solitary confinement.

The guard flung three blankets into the cell and blurted, 'One is for a mattress, one on you and use one as a pillow'. I was jolted with the slamming of the cell door. I looked around me and at the blankets that were, like me, tossed into the cell. The cement floor was covered with a thin, filthy carpet, too abhorrent to step on. There was a small sink to wash hands and face with foul-smelling water. The air in the cell reeked with a stench from the drain. I soon found out that if I was thirsty, that's where I could drink.

The steel door of the cell had a $12 \mathrm{~cm}$ hatch on it that had three steel bars so tight that when the hatch was opened from the outside, you couldn't even get a thin hand through them. There was no door handle from inside on the steel door. After you heard its rusty sound of closing, it would stay un-openable except externally, shutting out completely any contact with the world outside. It was a tiny cell that if measured with the breadth of my hand was only 14 hands by 11 hands, with its concrete walls piercing your soul with their thickness.

I stared at the old crumpled blankets piled on the floor. It was very demeaning. I threw them aside and sat down on the hard floor. But the hardness under me was nothing compared with the mental torture provoked in me. From that moment at the start, I came to feel the extreme meaning of humiliation. The slightest symbol is part of the process. Even with the type of clothes they give you, they humiliate you. My trousers were so long and big that one could 
fit into it like a sack. The blouse was so large that it reached to my knees and my hands were hidden in its sleeves. The slippers were so large that my feet were lost in them, taking away control over my steps. And then, there was the chador, veil and the blindfold. This set makes up all your belongings, plus other things that are too shameful to mention...

For several days and nights, I just froze on that carpet, completely awake, gaping at the cell door. My eyes were blurred from the glaring white. The walls seemed to close in on me and I could sense the pressure on my bones. Loneliness and total silence. It was only the sound of the guards' footsteps that told me life went on outside of this grave - even when you are unaware and dead in this tight and unbelievable cell. An existence in a tiny space where there is no one to listen to you and no one to say a word to you, to remind you that you are alive. The cell door would only open at food or toilet times and this was a big relief, to get some air in to the cell.

Everything is arranged in such a way to tell you that you are nothing and worthless, a piece of trash - a designation I kept hearing during the interrogations. Everything was cleverly and carefully designed for tormenting. All of a sudden, they lock you in a suspended state, in absolute unknowing. Just solitary isolation as blank as the walls, making you want to scream. I was beginning to lose my mind not knowing what to do. All memories of all sizes from my childhood kept passing before me like a non-stop movie.

Some were bitter and some were sweet ones. The trouble is that, in such a repulsive atmosphere, the sweet ones dissolve in a blink but the bitterness of the bad memories linger on. So, you keep talking to yourself non-stop. You ask the question and you answer it. You condemn yourself and you defend yourself, or, in your mind, you hang yourself. Only your tongue is moving and you wish someone would open the cell door and say something, even if it was to swear. You either hear yourself or hear the deadly silence.

Even when you are quiet and not speaking, it is your thoughts in that terminal silence and utter isolation from the outside world that controls your body, mind and spirit. Such loneliness that confronts you with yourself, demolishes you and impinges upon your soul in such an adverse way that can never be erased. You can only try to come to a compromise with it.

I spent several months in a solitary cell, absolutely cut-off from outside world.

I was jailed in winter. In the heat of the summer, the temperature inside the cell matched the sun itself but we had to be in the same winter clothes, to smoulder and melt in that oven with constant drips of sweat.

My attention seemed so scrunched up in a sack and my mind so pressed that I wasn't able to dissect my thoughts or empty the sack. I couldn't get release from my thoughts being munched up and tossed about and confused. I wished there was a sound to bring me back to myself.

The deadening loneliness and silence, together with the unbroken glare of the florescent lamps drill into you that it is always day. Despite the tricks I used to keep track of days and numbers, I would suddenly lose sense of time and space and float in a hazy perplexity.

Every time the cell door would open and a stretched hand with a bowl of food would appear, the sense of a wild animal in a cage would take hold of me. And when they slammed the door shut, all sorts of apprehensions would blight me. In the isolation of the cell, everything that has happened in your life, whether old and forgotten or new, mob you and badger you.

You try to lie down but you get weary, you lean on the wall and try to sit but you 
get fed up. You fall asleep, but how much can one sleep? You get up and march where you stand, 1000, 2000 to 5000, until you sit down again to start from zero once more, but time keeps stretching, without end. How can you keep time with an imaginary clock without the arms? Every moment begets a thousand feet and every foot a thousand branches, like a monstrous giant centipede walking all over your soul to crush it.

You long to be able to talk with someone, even for a few moments, and for your ears to hear a voice in this deadly silence. You only see the prison guards who appear and disappear like robots, opening the cell door to hand in a plate of food, or take you to the toilets or shower without an exchange of a single word. Here is a forgotten place outside of this planet. I'm not even allowed to knock on the wall. I am losing it all in this utter isolation.

I had become a stranger to myself. There were so many little things in life outside that I used to pass by indifferently, that had now become deeply desirable for me. I wished I had a watch to count the passing of the time, perhaps the seconds would become shorter! I wished I had a mirror to remember myself.

Food came with a disposable plate and spoon. I would hide one spoon for each day and when there was seven, I would hide one spoon under my mattress to count a week. But one day, I was looking under my mattress and in amazement said, why have I collected such a lot of spoons?! I thought I was going mad. The forgetfulness that had come to me due to the loneliness of the cell gave me an odd sense. As though I was thrashing about in a swamp of unknown, filling up my lungs with stinking water.

Time was passing dead slow and every moment stretched into a century. After a while you forget everything. No matter how I tried with my brain, I could not even remember what my appearance used to be like. A tormenting feeling that I had even forgotten my identity. I wanted to pull out of my throat all my insides and crush them under my feet. A perplexing and horrific feeing impossible to explain. Time is your enemy and you become your own foe as your mind forces you to confront yourself and wrestle with yourself. This is exactly the outcome they want.

How can time be spent in the cell of solitude and silence? Your thoughts bounce off the walls and each becomes a bullet ricocheting back to you. They hit you in such vulnerable parts that you freeze silent and stock-still.

In the mornings when the guard came to open the door of the cell to let me out to use the toilet, with a degrading look on her face, she would tightly hold her nose with her scarf so that she wouldn't throw up, because of the stench of the cell. Just with her head, she would point to me to get out. As for me, I had been saturated with that foul smell in the cell, for I had to breathe in the smell of the filthy drain all the time. Although, I confess that bearing the smell of the drain that filled the cell had become far easier than the deadly, maddening isolation.

If I were to tell you of just a day in the cell, moment by moment, I am sure even you would get bored. Every day was a copy of the previous day, but worse. All it was, repeating of words upon words, sometimes without thought, just uttering unconsciously as if you want to convince yourself that you are still in the world of the living! I must confess that, what this loneliness, humiliation and self-struggle did to me in this solitary cell has been engraved on my spirit and is too deep to be removed.

Whatever they do to you is with the aim of humiliating and degrading you in order to defeat and crush you, take your self-confidence from you and make from you something other than who you are, so that you are 
not be able to locate your true self.

Time doesn't move. Everyday seems a hundred days and more. Your yearnings melt bit by bit into the terrain of your dreams and you age as the silence of your cell tethers you with the realms of death. I craved an ache to occupy me so that the assault of the termites of my thoughts wouldn't devour my brain.

During the nights, in the fixed silence, when you wouldn't even hear a footstep, I would hear sounds of screaming, and I would cringe with fear. Here, no one has a name. I, as a prisoner, am just a number. The interrogator is known by a pseudo name and even the prison guards have bogus names. You only know them by their faces.

The prison guard calls me: 'You have cross-examination (interrogation), quick! Get ready!' But, then I have to stand blind-folded and facing the wall for hours waiting the interrogation and no one has taken any notice of me! Interrogation sessions involved times of standing blindfolded, facing the wall for hours until your knees start shaking and my back pain seared across my body. I would continually tell myself to persevere, don't show weakness that would make them gleeful, be strong! However, when you are strong, you get more hurt. Because, while you don't want to show yourself weak but tough, you get drained from within.

Right when there is no more strength to walk, they shout at you to come.

So, with a bizarre wobble and stiff legs, I follow the guard. Now I am sitting on a chair facing the wall. Perhaps for the show that he is about to perform on me, he allows me to lift my blindfold slightly to frighten me. Endless questions in circles. Nonsense questions. All the same process of humiliation and denigration. The interrogator resumes his questioning with dirty words. But words weren't enough and now he had made himself comfortable between my legs and I can see from underneath my blindfold how he wants to devour me with his filthy looks. While he is describing an imaginary sexual relationship between me and a friend of my father, his face becomes red hot, his eyes blood red and I feel the heat of his breath on me. My heart is about to stop. My mouth is severely dry and I don't know what he will do next.

Every time, in every session, he wanted me to affirm how I enjoyed the way he illustrated this abhorrent imaginary sexual relationship!

My body on the chair had frozen and I could feel my icy frame. The pen had jammed in my fingers and was motionless on a dot on the paper. There was no escape, not even a move on the chair. He would then ridicule me and, with his grimy grin tell me: 'I will continue this until you answer'.

When the assistant prosecutor couldn't get the answer he was looking for from me, he yelled at me: 'Get lost out of the room!' I kept spinning around myself, not finding the door. When they threw me back into my cell, the reverberation of his shouts kept ringing in my head. Like a little child, I longed for my mother's arms to hide my head in her bosom and to be embraced so that I could get away from the maddening scream of this man.

In this solitary cell, his screaming brought back to my mind one of my childhood's worst nightmares vividly, a traumatic experience I had almost forgotten that suddenly came back. But now there was no escape. There were walls everywhere. I was shaking and my teeth were clattering. I couldn't tell where I was. I believed I was buried alive. I sank my head under the blanket. Then out again, but the walls and silence were staring at me.

I wanted him to hit me, so that, when I returned to that stinking cell, I could agonize with pain, rather than for those degrading 
thoughts they had imputed on me to return to my head in the silence and loneliness of that cell. Physical pain would be, odd it might seem, a relief. So, I said, "Hit me, why don't you hit me?"With a sneering look and a mocking smile the interrogator said: "We don't do that here" - even remembering his grin by saying that tormented me in the cell. The most painful part is when people ask you, 'Did they also beat you in prison?' and when the answer is negative, they say oh, it's so good that they didn't harm you!!! But how can I tell them that my soul has received such a beating that it is full of injuries, stitches and deep infections, albeit unseen... but people believe only what they can see. Physical punishments are minor compared to what they systematically do to your spirit, a slap in the face, a kick or a punch.

The real torture begins after the interrogation, when you are alone in the cell, when there is you and the four walls, as if in a steel vault with an intense light in your eyes. On your own, everything that they did to you rushes back. Curiously, this film is being shown whichever way you turn your face. You close your eyes, but you can see the pictures and hear the echoes. The cell walls devour me. I put on my blindfold. You don't want to see anything and, those obscene words that drag you to the bottom of shame and humiliation and singe your ears, churn all your emotions. You hate yourself. As if someone is crumpling your heart. You hear its beats slowing down and flatlining. In my vexation, I bang my head several times to the concrete wall of the cell.

When you are tortured physically, you have pain to indulge in and bear. It doesn't give you time to wallow in your useless thoughts and you learn to live with your pain somehow. They recede after some time and their traces gradually disappear and one returns to normal. But that's not what they want. They want you to face only the onslaught of your futile and bewildering thoughts mixed with degradation in that deadening loneliness and muteness of the cell. They want you to lose time and space, forget your identity and, in distress and delusion be ready to face the interrogator again and again. They place you in this hell of delusive thoughts so that you can destroy yourself.

You are troubled even with the thought of suicide, wanting to be free from such a blight of torment. But there isn't anything to show how to release yourself of this regurgitation of mind. You wish someone would open the cell door and say, 'we have come to take you to be hanged'. I wished they would finish it all before I became a total lunatic and before my delusions would destroy my mind any further.

I do not recognize myself. I am losing my identity. In this stifling silence, I only hear myself talking and talking, but what I long for is another voice that can liberate me from this state suspended between illusions and reality.

Then, at times, the interrogators resort to rape to degrade you completely and destroy you by pushing you to the limit. It is when a prisoner has no means of blocking this act and the woman is lead like a sheep to the slaughter, defenceless, that she is forced to give in to such violation.

And, later, in the cold space of loneliness, this act keeps getting repeated, and repeated. You scream, you crunch your teeth, you bury your head in the filthy blanket and shout to get this sewage out of your awareness. But it's futile. Even if you doze off out of sheer exhaustion, nightmares, more vivid, will come.

Loneliness and loneliness again. The white jail cell of your loneliness. Floating in a weightless confusion. The air in the cell was suffocating and unbearable, as if the walls themselves were grabbing my essence from inside to devour. The ceiling was pressing on 
my face, as if to smother me. There was a barrage of thoughts of all shapes coming at my brain from every direction and bombarding my spirit. It was like a hundred arms had projected out of the walls to crush my bones. I couldn't tell where I was or what was going on. Total loneliness. I seemed to be toiling, hemmed in by walls in this stifling hush.

The white lights on the ceiling of the cell never went out, so the walls shone more brightly than they actually were, causing my eyes to twitch and go blank. To turn off the lamps, I would fold my Islamic scarf into a ball and throw it up to them, but to no effect. I had known these types of lamps in the market where the sellers wanted to shine light on their fruit to make it look bigger or more colourful to fool the buyers. I had got brown spots spread all over my hands and neck. Maybe on my face also, and I would get more tense as I didn't have a mirror to see. Maybe it was from those bright lights, the filthy blankets or the grimy carpet, or maybe they were just in my imagination!

One day when, after I had been persecuted to the maximum, I returned to the cell and I banged my head to the wall in ultimate frustration. The next-door cell thought I was knocking to her, so she answered me with two knocks! In all my brokenness, a faint smile came to my lips out of this little knock. I guessed that someone else in that cell was sharing her loneliness with me.

They sometimes commit rape with what they do. And they sometimes commit rape with the things they say to you, searing images that will never leave a prisoner's mind. That's humiliation. During the day in the presence of other people, maybe these thoughts become a bit hazy, but when alone at night, the screen rolls open and the pictures start flashing, dragging you to the enduring loneliness of the confinement. The utter seclusion and images are so penetrative that, like in hardened cement, they can never be removed from your soul. This tiny cell of being alone, drowns you in such deep delusions that the whole spirit screams out of acute pain. A silent scream that no one hears or feels. Then you are left with voices churning inside you, as if thousands of lunatics are chanting.

They come and say, you'll be released tomorrow. So, in that prolonged night, you make it to the morning with a thousand hopes. But there follows many nights that feel 100-years long. Nights and days pass but no one comes to open your cell door and that hope in anticipation that you believed in eventually comes to destroy you. Even in this, every little detail has been so planned, in order to trap you in trite thoughts and illusions, to distant you and remove you from the real world and what you used to be. This way, you won't be able to find yourself in that multitude of facts and phantoms.

Gradually and bit by bit, you begin to forget the faces of your dear ones. When I saw myself in the mirror of the isolation room where I had been hospitalized, I could not recognize the woman in the mirror who was staring at me.

Prison is a lawless city, full of insults, debasement, delusions and a thousand other unspeakable things. Then, when you get suddenly thrown out over those high walls, you become suspended in nowhere. You no longer belong to the prison nor are you of the outside world. You are hung between the two spaces.

Insomnia follows me since torture. After years, no full remedy for that until now. The images and impressions that become your nightmares and give you insomnia are tangible, permeate the whole of your mind. In fact, they become part of your being.

You are left with the new you whom only you know, and it is a hidden torment because 
others don't understand you. You have left parts of your personality and character behind those bars and have come out with an altered mentality and disposition. Your values have changed and so has your world. Now, even in a room with twenty people, you feel alone and in exile. Just the fact that they don't understand you is loneliness. These are the wounds of the soul sealed into your being. Especially at night, sometimes you go back to the cell. The humiliation comes back and you can't stop condemning yourself and your interrogators, you don't stop talking, not even for a moment, unless you fall asleep.

It is enough for a scent, a familiar face, the surroundings of a room or something said, to hurl you back to the dark atmosphere of the persecuting cell. My soul is filled with impressions that even the passage of time will not be able to fade.

These are the scars of torture, the scars of psychological torture.
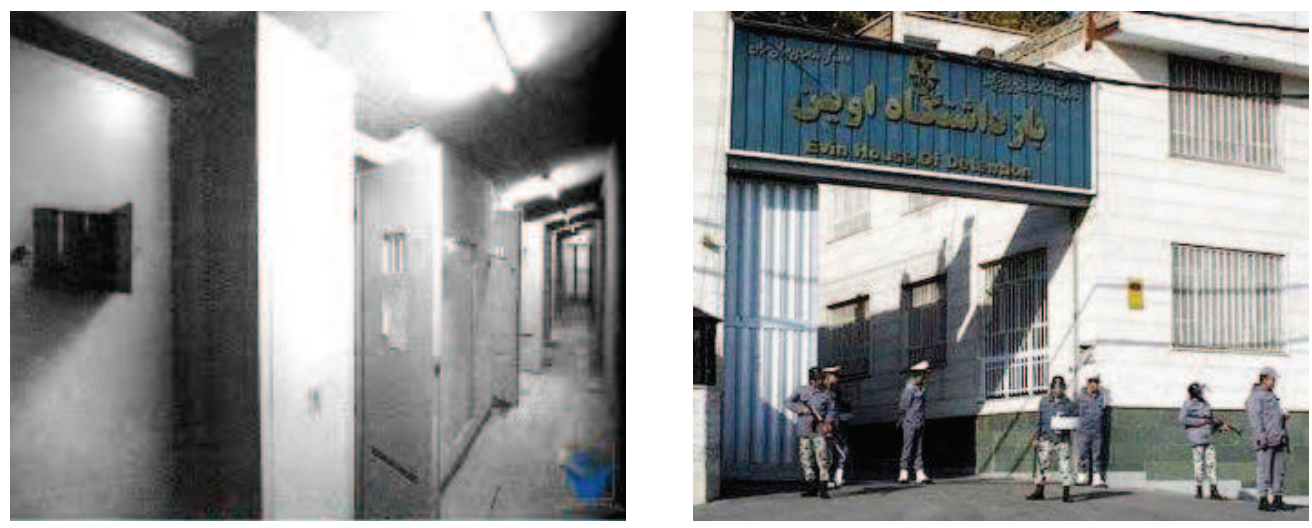